\title{
BIROKRASI GOOD GOVERNANCE SERTA ARTI MAKNA PENDIDIKAN POLITIK
}

\author{
ABDUL HIJAR ANWAR \\ Sekolah Tinggi Ilmu Hukum Padang \\ abdulhijaranwar@gmail.com
}

\begin{abstract}
Realizing good governance, the Indonesian government, both central and regional, needs to immediately carry out bureaucratic reforms that are not only at the level of commitment but also at the level of real life. It is hoped that this will reduce bureaucratic pathologies such as mal-administration that leads to corruption, collusion, and nepotism. Max Weber's legal rational bureaucracy concept is actualized in Indonesia with various advantages and disadvantages as seen from the behavior of the bureaucracy. Bureaucratic behavior arises when there is an interaction between individual characteristics and bureaucratic characteristics; especially with the various issues that are developing and current law enforcement related to bureaucratic pathology. Gradually, in Indonesia, bureaucratic reform is carried out in the dimensions of institutions, apparatus resources, management, and culture/mind set. Both the central government and local governments should carry out bureaucratic reform through consistent and sustainable learning organizations, taking into account critical success factors.
\end{abstract}

Keywords: Bureaucracy, Good Governance, Political Education.

Abstrak: Mewujudkan tata pemerintahan yang baik (good governance), maka pemerintahan Indonesia baik pusat maupun daerah, perlu segera melakukan reformasi birokrasi yang tidak hanya pada tataran komitmen saja tetapi juga dilandingkan dalam tataran kehidupan nyata. Hal ini diharapkan akan dapat mengurangi patologi birokrasi seperti terjadinya mal-administrasi yang mengarah pada korupsi, kolusi, dan nepotisme. Konsep birokrasi Max Weber yang legal rasional, diaktualisasikan di Indonesia dengan berbagai kekurangan dan kelebihan seperti terlihat dari perilaku birokrasi. Perilaku birokrasi timbul manakala terjadi interaksi antara karakteristik individu dengan karakteristik birokrasi; apalagi dengan berbagai isu yang berkembang dan penegakan hukum saat ini yang berkaitan dengan patologi birokrasi. Secara gradual, di Indonesia reformasi birokrasi dilakukan dalam dimensi kelembagaan, sumberdaya aparatur, ketatalaksanaan, dan kultur/ mind set. Baik pemerintah pusat maupun pemerintah daerah, hendaknya melakukan reformasi birokrasi melalui organisasi pembelajaran yang konsisten dan berkelanjutan, dengan memperhatikan critical success factors.

Kata Kunci: Birokarasi, Good Governance, Pendidikan Politik

\section{A. Pendahuluan}

Pentingnya memahami politik, karena politik pada dasarnya merupakan suatu fenomena yang berkaitan dengan manusia yang selalu hidup bermasyarakat. Pada kodratnya ia adalah makhluk sosial yang selalu hidup dinamis dan berkembang. Karena itulah politik selalu merupakan gejala yang mewujudkan diri manusia dalam rangka proses perkembangannya. Karena manusia adalah inti utama dari politik, maka apapun alasannya pengamatan atau telaah politik tidak begitu saja meninggalkan faktor manusia. Dengan demikian dengan memahami arti politik sessungguhnya khususnya bagi para kaum muda intelektual dan masyarakat bisa memahami bahwasannya politik ada karena untuk memenuhi kebutuhan masyarakat itu sendiri..

Anak muda adalah garda terdepan dalam perubahan kemajuan suatu daerah, sehingga peran mereka sangat penting dalam bingkai politik, bukan hanya penting untuk ikut mencoblos ataupun penting dalam menjadi tim sukses, akan tetapi hal yang paling penting bagi anak muda adalah memberikan ruang politik untuk berpartisipasi aktif dalam pembangunan daerah. Melihat keadaan politik di Indonesia yang semakin miris, tentunya diperlukan suatu perubah. Perubahan yang sangat berarti bagi bangsa Indonesia. Dan dalam hal ini peran pemudalah yang sangat di butuhkan. Hampir setiap kegiatan pemilu, peran pemuda cukup mendominasi. 
Tak dapat dipungkiri, dukungan pemuda dalam setiap pemilu tak pernah surut. Tidak saja di Indonesia, di setiap Negara manapun partisipasi pemuda dalam pemilu selalu dominan. Memang pada awalnya para pemuda hanya berkontribusi sebagai masyarakat yang memilik hak pilih. Tetapi sebenarnya para pemuda di Indonesia memiliki potensi yang lebih dari sekedar pemilih aktif. Pemuda dapat berkontribusi langsung secara aktif dalam dunia perpolitikan di Indonesia. Kemampuan pemuda Indonesia dalam berpolitik tidak dapat diremehkan lagi. Pemikiran mereka yang kritis terhadap kebijakan-kebijakn politik dapat menjadi suatu pembaharuan dalam dunia perpolitikan.

Pendidikan politik bertujuan mengarahkan partisipasi dari seluruh masyarakat untuk menopang Pilkada secara adil. Hal ini tidak berlebihan mengingat partisipasi masyarakat dalam Pilkada menjadi tolok ukur terhadap pembangunan demokrasi ke depannya. Kualitas demokrasi Indonesia tercermin dalam kedewasaan dan kesadaran dalam berpolitik. kesadaran politik adalah kesadaran akan hak dan kewajiban sebagai warga negara. Tingkat kesadaran politik diartikan sebagai tanda bahwa warga masyarakat menaruh perhatian terhadap masalah kenegaraan dan atau pembangunan. Pendidikan politik harus segera digalakan kembali disetiap lini kehidupan, baik lewat intitusi pemerintah maupun non pemerintah; baik secara formal maupun nonpormal, sehingga permasalahan sosial yang begitu berbahaya seperti berita hoax, manuver politik saling tikam, dan perpecahan akibat issue SARA bisa segera diatasi. Karena ketika pendidikan politik sudah berjalan dan dapat dipahami, maka setiap warganegara Indonesia akan turut membangun masyarakat dan negaranya, yang dilakukan bersama-sama dengan pemerintah. Dan yang terpenting adalah setiap sarana pendidikan politik yang ada, haruslah melaksanakan tuganya dengan baik yaitu mencerdaskan dan memberikan pemahaman kepada mahasiswa dan rakyat secara baik, bukan malah "menyesatkan atau membodohi" rakyat.

\section{B. Metodologi Penelitian}

Metodologi penelitian dalam artikel ini adalah metodologi penelitan hukum, yang bersifat normatif, terkait birokrasi, good governance serta arti makna pendidikan politik. Membangun sebuah konstruksi membutuhkan pondasi yang menjadi tumpuan beban bidang bangunan. Konstruksi merupakan sebuah objek bangun yang terdiri dari berbagai struktur sebelum menjadi bangunan utuh. Sementara pondasi yang menjadi struktur dasar konstruksi bangunan memiliki peran penting, karena sumber kekuatan sebuah bangunan terdapat pada pondasi tersebut. Untuk memperoleh keberhasilan dalam pelaksanaan konstruksi, perencanaan matang juga perlu diperhatikan secara terperinci seperti metode penentuan pembangunan, biaya, keselamatan kerja, dan lain sebagainya

\section{Hasil dan Pembahasan}

\section{Makna pendidikan politik}

Makna pendidikan politik sama dengan sosialisasi politik, yaitu proses menyampaikan atau menyebarkan program-program pemerintah (penguasa) kepada m;asyarakat dalam suatu sistem politik. Pendidikan politik merupakan upaya mengenalkan suatu sistem politik pada individu dan menentukan reaksi terhadap gejala-gejala politik dalam sistem tersebut. Konsep pendidikan politik dan sosialisasi politik memiliki arti yang berdekatan atau hampir sama sehingga dapat digunakan secara bergantian. Pendidikan adalah proses pengubahan sikap dan tata laku seseorang atau kelompok orang dalam usaha mendewasan manusia dengan upaya pengajaran dan pelatihan. Pendidikan politik merupakan sebuah usaha untuk menciptakan warga negara yang benar-benar melek politiknya. Selain itu, pendidikan politik sebagai usaha dalam mencapai hak politik yang dimiliki setiap warga negara dalam membangun clan menjalankan suatu sistem politik yang ada. Disamping itu warga negara diharapkan mampu berpartisipasi aktif dalam sistem politik yang menuntut kedewasaan berpolitik untuk menciptakan kedamaian bermasyarakat, berbangsa dan bernegara. 
Ada sembilan tujuan pendidikan politik yang paling sulit diwujudkan. Bisa diliat dari Tujuan Instruksi Presiden No. 12 Tahun 1982 tentang Pendidikan Politik bagi Generasi Muda: 1) Sadar akan hak dan kewajiban serta tanggung jawab terhadap kepentingan bangsa dan negara; 2) Secara sadar taat pada hukum dan Undang-Undang Dasar; 3) Memiliki disiplin pribadi,sosial, dan nasional; 4) Berpandangan jauh ke depan serta memiliki tekad perjuangan untuk mencapai kehidupan yang lebih maju, yang didasarkan pada kemampuan objektif bangsa; 5) Secara sadar mendukung sistem kehidupan nasional secara demokratis; 6) Aktif dan kreatifdalam kehidupan berbangsa dan bernegara khususnya dalam usah; 7) Aktif menggalang persatuan dan kesatuan bangsa dengan kesadaran akan keanekaragaman bangsa; 8) Sadar akan perlunya pemeliharaan lingkungan hidup dan alam secara selaras, serasi, dan seimbang; dan 9) Mampu melaksanakan penilaian terhadap gagasan, nilai, serta ancaman yang bersumber dari luar Pancasila dan UUD1945 atas dasar pola pikir atau penalaran logis mengenai Pancasila dan UUD 1945.

Tujuan pendidikan politik yang paling sulit diwujudkan adalah aktif menggalang persatuan dan kesatuan bangsa dengan kesadaran akan keanekaragaman bangsa. Hal ini terjadi karena Indonesia merupakan negara kepulauan. Di mana memiliki beranekaragam suku, agama, etnis, atau budaya. Keberagaman tersebut bisa berdampak pada perpecahan serta memecah persatuan dan kesatuan. Perbedaan kebudayaan identik dengan daerah yang berbeda. Pembangunan yang tidak merata juga sebagai fakto penghambat dalam persatuan dan kesatuan. Kondisi itu harus diantisipasi dan dijaga oleh pemerintah untuk mereta dalam pembangunan. Wilayah Indonesia cukup luas, sehingga tidak ada masyarakat yang iri.

Dimensi pendidikan politik, terdiri dari: a) Political Knowledge; b) Political Skill; c) Political Competence; d) Political Engagement; e) Political Literacy; f) Political Awareness; g) Political Behavior; h) Political Ethics; i) Political Values; dan j) Political Action. Menurut saya yang paling penting adalah Political Knowledge. Karena pengetahuan pendidikan politik adalah proses pembelajaran dan pemahaman tentang hak, kewajiban dan tanggung jawab setiap warga negara dalam kehidupan berbangsa dan bernegara. Jika dikaitkan dengan partai politik, pendidikan politik bisa diartikan sebagai usaha sadar dan tersistematis dalam mentransformasikan segala sesuatu yang berkenaan dengan perjuangan partai politik tersebut kepada massanya agar mereka sadar akan peran dan fungsi, serta hak dan kewajibannya sebagai manusia atau warga negara. Pemahaman masyarakat hingga saat ini masih banyak yang beranggapan bahwa sistem politik itu bukan urusan mereka melainkan urusan pemerintah, sehingga masyarakat masih ada yang dibodoh-bodohi atau diberikan janji-janji manis. Dalam realitanya atau penerapannya tidak sesuai dengan yang telah dijanjikan ketika sudah berhasil duduk.

Jika diibaratkan sebuah negara, konstruksi bisa dianalogikan sebagai sistem pemerintahan dengan birokrasi sebagai pondasinya. Birokrasi memang sebuah kata yang tidak asing untuk didengar, namun sulit untuk didefinisikan secara harfiah. Birokrasi sendiri berasal dari bahasa Inggris, yaitu bureau dan cracy yang bisa diartikan sebagai suatu organisasi yang memiliki rantai komando dengan struktur berbentuk piramida dengan maksud mengorganisasi secara teratur sesuatu melalui sebuah sistem guna mencapai tujuan tertentu (Deputian Reformasi Birokrasi, 2019). Kamus Besar Bahasa Indonesia (KBBI), mendefinisikan birokrasi sebagai sistem pemerintahan yang dijalankan oleh pegawai pemerintah karena telah berpegang pada hierarki dan jenjang jabatan. Sementara Maximilian Weber, atau lebih dikenal dengan Max Weber, seorang ahli ekonomi politik dan sosiolog dari Jerman, yang juga merupakan salah satu pendiri ilmu sosiologi dan administrasi negara, menerjemahkan birokrasi sebagai bentuk organisasi yang penerapannya berhubungan dengan tujuan yang hendak dicapai. Birokrasi dimaksudkan sebagai suatu sistem otorita yang ditetapkan secara rasional oleh berbagai peraturan. Selain itu, birokrasi juga dimaksudkan untuk mengorganisir secara teratur suatu pekerjaan yang harus dilakukan oleh orang banyak.

Sebagai pondasi dalam sistem pemerintahan, dalam birokrasi terdapat aparatur yang menjalankan roda pemerintahan. Namun birokrasi tidak bisa hanya dilihat dari segi aparatur yang menjadi abdi negara, melainkan harus dilihat secara keseluruhan sebagai sebuah sistem 
yang sangat kompleks sebagai pendorong jalannya roda pemerintahan. Melihat kondisi birokrasi di Indonesia sejak beberapa tahun belakangan, siapapun akan berpandangan pesimis bahkan sinis terhadap birokrasi. Hal ini terjadi mengingat kompleksitas masalah yang ada dalam birokrasi di Indonesia. Struktur organisasi yang terlalu gemuk dan tidak fit dengan fungsi, payung hukum yang kontradiktif dan ambigu, rekrutmen yang tidak objektif, maraknya praktik KKN, integritas aparatur yang masih bermaslah, pelayanan publik yang tidak berkualitas dan transparan, kurang inovatif serta sistem dan budaya kerja yang belum terbangun menjadi potret masalah birokrasi di Indonesia (Thoha Miftah dan Agus Dharma, 1999).

Sejak era reformasi, kondisi birokrasi di Indonesia memang masih belum bisa dikatakan berada pada posisi yang baik, mengingat mentalitas birokrat masih belum menunjukkan kepedulian terhadap perubahan dan tuntutan masyarakat akan pelayanan. Banyak birokrat yang menjadi arogan dan seolah apatis dengan menganggap bahwa rakyatlah yang membutuhkan seorang birokrat. Selain itu, praktik korupsi, kolusi, dan nepotisme (KKN) juga tidak bisa dipungkiri kerap terjadi di instansi pemerintah. Komitmen dan konsistensi pemerintah untuk mewujudkan birokrasi yang bersih, akuntabel, dan profesional pun terus dipertanyakan. Namun seiring perkembangan zaman yang tidak bisa dihindari, peta birokrasi di Indonesia kini dipaksa untuk digeser agar berjalan sesuai dengan pakemnya. Pemerintah pun bergerak untuk merumuskan sebuah peraturan agar menjadi landasan pelaksanaan reformasi birokrasi dengan mengeluarkan Peraturan Presiden No. 80 Tahun 2011 tentang Grand Design Reformasi Birokrasi Indonesia 2010-2025.

Lembaran Grand Design Reformasi Birokrasi Indonesia, disebutkan bahwa visi reformasi birokrasi adalah terwujudnya pemerintahan kelas dunia. Untuk mewujudkan visi tersebut, artinya pemerintah harus memiliki birokrasi yang profesional dan berintegritas dan mampu hadir lebih dekat kepada masyarakat dengan memberikan pelayanan prima. Pemerintah pun telah menyusun strategi reformasi birokrasi nasional untuk mencapai tiga sasaran reformasi birokrasi, yaitu terwujudnya pemerintahan yang bersih dan bebas KKN, meningkatknya kapasitas dan akuntabilitas kinerja birokrasi, serta meningkatnya kualitas pelayanan publik. Strategi pemerintah tersebut dibagi menjadi dua kerangka, yaitu makro (sebagai kerangka regulasi nasional) dan mikro (sebagai program/kegiatan pada tingkat instansi). Pada tingkat makro, tiga strategi telah ditetapkan, yaitu melalui Rancangan UndangUndang (RUU) Aparatur Sipil Negara (ASN), RUU Administrasi Pemerintahan, dan Sembilan Program Percepatan Reformasi Birokrasi. Sembilan program tersebut adalah penataan struktur birokrasi, penataan jumlah, distribusi dan kualitas PNS, sistem seleksi dan promosi secara terbuka, profesionalisasi PNS, pengembangan sistem elektronik pemerintah (E-Government), peningkatan pelayanan publik, peningkatan transparansi dan akuntabilitas aparatur, peningkatan kesejahteraan pegawai negeri, dan efisiensi belanja pegawai.

Sementara di tingkat mikro, pemerintah telah menetapkan Grand Design Reformasi Birokrasi 2010-2025, Road Map Reformasi Birokrasi, dan pedoman pelaksanaan lainnya yang menyasar delapan area perubahan melingkupi organisasi, tatalaksana, sumber daya manusia aparatur, peraturan perundang-undangan, pengawasan, akuntabilitas, pelayanan publik, dan budaya kinerja. Pemerintahan Presiden Joko Widodo nampaknya menyadari betul bahwa reformasi birokrasi di Indonesia berjalan sangat lambat akibat pola pikir dan perilaku birokrat yang belum berkomitmen untuk berubah. Oleh karenanya, tepat jika Presiden Joko Widodo kemudian mengeluarkan semangat perubahan melalui "Revolusi Mental" Kemudian bagaimana menilai tingkat keberhasilan pelaksanaan program percepatan reformasi birokrasi hingga saat ini? Ada tiga indikator utama yang bisa memberikan penilaian terhadap tingkat keberhasilan percepatan reformasi birokrasi, yaitu Indeks Persepsi Korupsi, Peringkat Kemudahan Berusaha (ease of doing business/eodb) dan jumlah instansi pemerintah yang memiliki akuntabilitas tinggi. Berdasarkan survey Lembaga Tranparency International (TI), indeks persepsi korupsi di Indonesia tahun 2019 mengalami perbaikan. Indoensia menempati 
posisi 88 dari 168 negara, di mana pada tahun sebelumnya, indeks persepsi korupsi Indonesia berada pada peringkat 107 .

Begitu pula dengan akuntabilitas instansi pemerintah juga terus mengalami perbaikan. Hal tersebut tercermin dari banyaknya komitmen yang muncul diberikan pimpinan instansi, baik pusat maupun daerah. Dengan banyaknya komitmen tersebut, mengindikasikan besarnya kepedulian pimpinan setiap instansi pemerintah untuk melakukan perubahan dalam rangka memperbaiki tata kelola pemerintahan. Sadar atau tidak, pergeseran pandangan terhadap birokrasi yang korup mulai terlihat. Perubahan yang terjadi dalam birokrasi karena tuntutan zaman, telah berpengaruh terhadap jalannya pemerintahan saat ini. Hal tersebut terlihat dari berbagai survey yang dilakukan oleh lebaga-lembaga survey, seperti menurunnya indeks persepsi korupsi dan membaiknya peringkat kemudahan berusaha. Dengan demikian, bukan tidak mungkin visi reformasi birokrasi untuk mewujudkan pemerintahan kelas dunia perlahan akan tercapai. Optimisme tersebut nampaknya memang harus dijaga seiring dengan berbagai perbaikan yang telah diupayakan secara simultan oleh pemerintah demi terwujudnya good and clean government.

\section{Konsep Birokrasi Dan Good Governance Max Weber Di Indonesia}

Max Weber menciptakan mode 1 tipe ideal birokrasi yang menjelaskan bahwa suatu birokrasi atau administrasi mempunyai suatu bentuk yang pasti dimana semua fungsi dijalankan dalam cara-cara yang rasional. Tipe ideal itu menurutnya bisa dipergunakan untuk membandingkan birokrasi antara organisasi yang satu dengan organisasi yang lain. Menurut Max Weber bahwa tipe ideal birokrasi yang rasional tersebut dilakukan dalam cara-cara sebagai berikut (Miftah Thoha, 1991): 1) Pertama, individu pejabat secara personal bebas, akan tetapi dibatasi oleh jabatannya manakala ia menjalankan tugas-tugas atau kepentingan individual dalam jabatannya. Pejabat tidak bebas menggunakan jabatannya untuk keperluan dan kepentingan pribadinya termasuk keluarganya; 2) Kedua, jabatan-jabatan itu disusun dalam tingkatan hierarki dari atas ke bawah dan ke samping. Konsekuensinya ada jabatan atasan dan bawahan, dan ada pula yang menyandang kekuasaan lebih besar dan ada yang lebih kecil; 3) Ketiga, tugas dan fungsi masing-masing jabatan dalam hiearki itu secara spesifik berbeda satu sama lainnya; 4) Keempat, setiap pejabat mempunyai kontrak jabatan yang harus dijalankan. Uraian tugas (job description) masing-masing pejabat merupakan domain yang menjadi wewenang dan tanggung jawab yang harus dijalankan sesuai dengan kontrak; 5) Kelima, setiap pejabat diseleksi atas dasar kualifikasi profesionalitasnya, idealnya hal tersebut dilakukan melalui ujian yang kompetitif; 6) Keenam, setiap pejabat mempunyai gaji termasuk hak untuk menerima pensiun sesuai dengan tingkatan hierarki jabatan yang disandangnya. Setiap pejabat bisa memutuskan untuk keluar dari pekerjaannya dan jabatannya sesuai dengan keinginannya dan kontraknya bisa diakhiri dalam keadaan tertentu; 7) Ketujuh, terdapat struktur pengembangan karier yang jelas dengan promosi berdasarkan senioritas dan merit sesuai dengan pertimbangan yang obyektif; 8) Kedelapan, setiap pejabat sama sekali tidak dibenarkan menjalankan jabatannya dan resources instansinya untuk kepentingan pribadi dan keluarganya; dan 9) Kesembilan, setiap pejabat berada di bawah pengendalian dan pengawasan suatu sistem yang dijalankan secara disiplin.

Sifat yang menonjol dari konsep birokrasi Max Weber yaitu (Ali Abdul Wakhid, 2011): 1) Harus ada prinsip kepastian dari hal-hal kedinasan, diatur dengan hukum, yang biasanya diwujudkan dalam berbagai peraturan atau ketentuan administrasi. 2) Prinsip tata jenjang kedinasan dan tingkat kewenangan, agar terjadi keserasian kerja, keharmonisan dan rasionalitas. 3) Manajemen yang modern haruslah didasarkan pada dokumen- dokumen tertulis. 4) Spesialisasi dalam manajemen atau organisasi harus didukung oleh keahlian yang terlatih. 5) Hubungan kerja di antara orang dalam organisasi didasarkan atas prinsip impersonal. 6) Aplikasi kelima tersebut pada organisasi pemerintahan, juga semua terikat dengan organisasi pemerintahan yang tidak bisa menghindar dari sentuhan aktivitas pemerintahan. Sejak bergulirnya era reformasi, berbagai isu ataupun pemikiran dilontarkan para pakar berkaitan dengan bagaimana mewujudkan tata pemerintahan yang baik (good 
governance), di antaranya dilakukan melalui reformasi birokrasi. Upaya tersebut secara bertahap dilakukan baik oleh pemerintah pusat maupun pemerintah daerah (Provinsi dan Kabupaten/ Kota).Secara empiris birokrasi identik dengan aparatur pemerintah yang mempunyai tiga dimensi yaitu organisasi, sumber daya manusia, dan manajemen. Dalam pemerintahan, dimensi itu dikenal kelembagaan, kepegawaian dan ketatalaksanaan, yang merupakan unsur-unsur administrasi negara; kiranya dimensi tersebut dapat ditambah dengan kultur mind set. Konsep birokrasi Max Weber yang legal rasional, diaktualisasikan di Indonesia dengan berbagai kekurangan dan kelebihan seperti terlihat dari perilaku birokrasi. Perilaku birokrasi timbul manakala terjadi interaksi antara karakteristik individu dengan karakteristik birokrasi; apalagi dengan berbagai isu yang berkembang dan penegakan hukum saat ini yang berkaitan dengan patologi birokrasi (Trilestari, 2008).

Secara gradual di Indonesia dilakukan reformasi birokrasi dalam dimensi kelembagaan, sumberdaya aparatur dan ketatalaksanaan, baik oleh pemerintah pusat maupun pemerintah daerah. Apalagi dalam Undang-Undang Nomor 17 Tahun 2007 tentang Rencana Pembangunan Jangka Panjang Nasional Tahun 2005-2025 menetapkan bahwa: "Pembangunan aparatur negara dilakukan melalui reformasi birokrasi untuk meningkatkan profesionalisme aparatur negara dan untuk mewujudkan tata pemerintahan yang baik, di pusat maupun di daerah" (Sukarno, 2008). Berkaitan dengan organisasi pemerintahan terdapat tiga hal otoritas yang merupakan sumber legitimasi bagi pemerintahan yaitu: a) Otoritas Tradisional Mengklaim legitimasi dalam basis keaslian dan kekuasaan mengontrol yang diwarisi dari masa lampau dan masih dianggap ada atau berlaku sampai sekarang. Hal tersebut akan menciptakan hubungan pribadi secara intesif di antara atasan dan bawahan. b) Otoritas kharismatik. Sifatnya sangat personal memperoleh otoritasnya dari kualitas pribadi yang dibawa sejak lahir, yang mampu menimbulkan kesetiaan dari para pengikutnya. Dalam kharismatik tidak dikenal adanya aturan hierarki dan formalitas, kecuali adanya keinginan dasar akan kesetiaan pengikut terhadap pemimpin kharismatik. c) Otoritas legal rasional. Kebutuhan terhadap organisasi sosial yang berdasarkan stabilitas tetapi memberikan kesempatan adanya perubahan.

Sifat otoritas pribadi yang secara intensif berkembang dalam situasi Kharismatik dan penggunaan kekuasaan personal di dalam sistem Tradisional memberikan jalan kepada otoritas impersonal yang bersumber kepada peraturan. Lebih lanjut Max Weber mengemukakan bahwa legitimasi adalah dasar hampir semua sistem otoritas, dengan lima legitimasi yang berkaitan dengan otoritas yaitu: a) Peraturan yang sah, maka dapat menuntut kepatuhan dari para anggota organisasi. b) Hukum merupakan suatu sistem aturan abstrak yang ditetapkan pada kasus tertentu, sedangkan administrasi mengurus kepentingan organisasi yang dalam batas hukum. c) Manusia yang menjalankan otoritas, juga memiliki tatanan impersonal. d) Hanya qua member (anggota yang taat) yang benar-benar mematuhi hukum. e) Kepatuhan seharusnya tidak kepada tatanan impersonal yang menjaminnya untuk menduduki jabatan (Albrow Martin, 1996).

Selanjutnya Albrow mengemukakan rumusan Weber tentang delapan proposisi tentang penyusunan sistem otoritas legal atas dasar konsepsi legitimasi, yaitu: 1) Tugas-tugas pejabat diorganisir berdasarkan aturan yang berkesinambungan. 2) Tugas-tugas tersebut dibagi atas bidang-bidang yang dibedakan menurut fungsi, masing-masing dilengkapi dengan syarat otoritas dan sanksi-sanksinya. 3) Jabatan-jabatan tersusun secara hierarki, hak-hak kontrol dan komplain di antara mereka terperinci. 4) Aturan-aturan yang sesuai dengan pekerjaan diarahkan baik secara teknis maupun secara legal. Hal ini manusia terlatih diperlukan. 5) Sumber-sumber daya organisasi sangat berbeda dengan yang berasal dari para anggota sebagian individu pribadi. 6) Pemegang jabatan tidak sesuai dengan jabatannya. 7) Administrasi didasarkan pada dokumen-dokumen tertulis dan hal ini cenderung menjadikan kantor sebagai pusat organisasi modern. 8) Sistem-sistem otoritas legal dapat mengambil banyak bentuk, tetapi dilihat pada bentuk aslinya yaitu di dalam suatu staf administrasi birokratik. 